\title{
SUSPENSION AND EXPULSION OF BLACK STUDENTS FROM THE PUBLIC SCHOOLS: ACADEMIC CAPITAL PUNISHMENT AND THE CONSTITUTION
}

\author{
MARK G. YUDOF* \\ INTRODUCTION
}

The relationship between law and mathematics has been described as a "romance" which "has been for the most part a one-sided affair." Mathematicians historically have toyed with the idea of bringing their discipline to bear on social problems and their resolution, but lawyers and judges have proved to be a recalcitrant lot. Many lawyers apparently chose law school to escape those mysteries of all mysteries, mathematics and science. But, alas, our escape has proven to be an illusion. At every turn we are besieged with preference contours, choice sets, random samples, and statistical probabilities. $^{2}$ While many of us remain xenophobic to the core, greeting with hostility each new incursion into the world of "plausibility," "commonsense" and "humanistic" thought, ${ }^{3}$ frankness commands the admission that the affair has become serious. The one-sided romance has developed into a marriage of convenience, or, reflecting more recent conjugal innovations, a willingness to share the same quarters without the formalities of ceremony and family reception. ${ }^{4}$

Nowhere has the impact of this new relationship been more severely felt than with respect to the developing law of racial discrimination. ${ }^{5}$ It

\footnotetext{
* Professor of Law, University of Texas at Austin. I wish to express my appreciation to Professor David Kirp for his thoughtful comments on an earlier version of this article.

1. See Finkelstein, The Application of Statistical Decision Theory to the Jury Discrimination Cases, 80 HaRV. L. Rev. 338 (1966).

2. See generally Tribe, Trial by Mathematics: Precision and Ritual in the Legal Process, $84 \mathrm{HARV}$. L. REv. 1329 (1971).

3. But see note 5 infra.

4. Professor Tribe, while noting the "rapidly growing interest in the conjunction of mathematics and the trial process," has grave misgivings about the marriage of the two:

The literature of legal praise for the progeny of such a wedding has been litule short of lyrical. Surely the time has come for someone to suggest that the union would be more dangerous than fruitful. Tribe, supra note 2, at 1393.

5. See Bogen \& Falcon, The Use of Racial Statistics in Fair Housing Cases, 34 MD. L. REv. 59 (1974); Dimond, School Segregation in the North: There is But one Constitution, $7 \mathrm{HaRv}$. Civ. Rights-Civ. Lib. L. Rev. 1 (1972); Fiss, A Theory of Fair Employment Laws, 38 U. CHI, L. REv. 235, 268-70 (1971); Fessler \& Haar, Beyond the Wrong Side of the Tracks: Municipal Services in the Interstices of Procedure, $6 \mathrm{HARv}$. Civ. Rights-Civ. Lib. L. Rev. 441 (1971); Finkelstein, supra note 1 .
} 
used to be easy to identify race-conscious public policies; for usually state officials were quite willing to articulate their racial biases and specifically incorporate them into state laws. But in an age where civility commands verbal racial neutrality and where so much progress has been made toward racial justice, proof of discrimination is more complex. Now everything seems to turn on the significance of numbers. Has a school system failed to comply with its obligation to dismantle the dual school system because there are still some one race schools in the district or because the relative percentages of blacks and whites in the school district are not reflected in each public

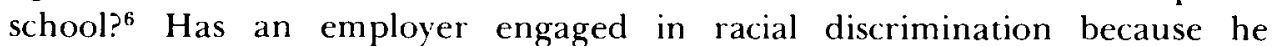
employs few blacks? Are colleges and graduate schools compelled or permitted to adopt affirmative action plans to increase minority enrollments because minorities are underrepresented in the student population? ${ }^{8}$ Is the process by which school board members are selected suspect if few blacks are appointed to the nominating panel? ${ }^{9}$ In each case, the question is not whether there is disproportional representation between racial groupsthere surely is: the question is what logical conclusion should be drawn from that fact.

The law has dealt with statistical evidence bearing on racial discrimination in an inconsistent manner. ${ }^{10}$ Judges tell us in jury discrimination cases that "figures speak and when they do, Courts listen." 11 The statistical showing that a county has a ten per cent black population and yet not a single black has served on a federal or state jury is sufficient to constitutionally damn the method of selecting jurors. ${ }^{12}$ On the other hand, Justice Rehnquist assured us in a welfare case arising under the Equal Protection Clause that courts must be wary of such "naked statistical argument"; for if such statistics suffice to demonstrate discrimination or to shift the burden of persuasion

6. See Swann v. Charlotte-Mecklenburg Bd. of Educ., 402 U.S. I (1971). See also Wright v. City of Emporia, 407 U.S. 451 (1972). See generally Kalven, The Supreme Cont, 1970 Term-Foreword: Even When a Nation is at War, 85 HaRv. L. REv. 3, 78 (1971).

7. See, e.g., Griggs v. Duke Power Co., 401 U.S. 424 (1971); Boston Chapter N.A.A.C.P. v. Beecher, 504 F.2d 1017 (1st Cir. 1974); The Vulcan Socy v. Civil Serv. Comm 490 F.2d 387 (2d Cir. 1973); Chance v. Board of Examiners, 330 F. Supp. 203 (S.D.N.Y. 1971). affd, 458 F.2d 1167 (2d Cir. 1972); Note, Business Necessity Under Title VII of the Civil Rights Act of 1964: A No-Alternative Approach, 84 YaLE L.J. 98 (1974).

8. See DeFunis v. Odegaard, 82 Wash. 2d 11, 507 P.2d 1169 (1973), vacated, 416 U.S. 312 (1974) (per curiam). See generally Kirp \& Yudof, DeFunis and Beyond, 6 Change no. 9, at 22 (1974); Ely, The Constitutionality of Reverse Racial Discrimination, 41 U. CHI. L. Rev. 723 (1974); O'Neil, Preferential Admissions: Equalizing the Access of Minority Groups to Higher Education, 80 YALE L.J. 699 (1971); Graglia, Special Admission of the "Culturally Deprived" to Law School, 119 U. PA. L. Rev. 351 (1970): Askin, The Case for Compensatory Treatment, 24 Rutgers L. REv. 65 (1969).

9. See Mayor of Phila. v. Educational Equality League, 415 U.S. 605 (1974).

10. This rather ad hoc approach toward probabilistic proof is apparent in many areas of the law. See Tribe, supra note 2 , at 1343-44.

11. Brooks v. Beto, 366 F.2d 1. 9 (5th Crr! 1966).

12. Id. 
Moreover, government is not allocating a scarce resource, and thus there is the grant classes, however lacking in racial motivation and however otherwise rational the treatment might be." ${ }^{13}$ In that case the Texas legislature had disfavored classes of welfare recipients in which the proportions of blacks and Mexican-Americans were highest. Yet a court of appeals recently held unconstitutional a method of allocating municipal services which, although ostensibly on the basis of need for the service, resulted in unequal services between blacks and whites. ${ }^{14}$ Even in the absence of proof of a discriminatory motive, the court required the defendants to satisfy a heavy burden to justify such inequalities.

Perhaps the principle underlying these cases is not so difficult to discern. What the courts may be saying is that a statistical showing of inequalities between the races in the enjoyment of public benefits is always relevant to the disposition of the case. It is sufficient in itself, however, only where the disproportionality is of such a magnitude as to make any nonracial explanation implausible or where, despite some lesser showing, there appears to be no rational, racially neutral explanation for the pattern of allocations. Thus the issue will turn on the character of the benefits, and statements with respect to the probative impact of the statistical evidence are simply conclusionary labels attached after the court has considered the likelihood of nonracial explanations for the state's classificatory scheme.

This standard reflects three related judgments. First, nearly every governmental activity may fall unequally on racial and economic groups within the society. Public transportation may be more beneficial to low-income minorities than to middle-income whites, just as more whites may utilize public golf and tennis courts. There are questions of need and taste which must be taken into account, and it is unthinkable that the courts should mechanically require equal enjoyment by racial groups with respect to all government programs. Equal access on the basis of relevant and racially neutral criteria will suffice. Second, as Justice Powell has artfully stated, there are cases "in which it cannot be assumed that all citizens are fungible for purposes of determining whether members of a particular class have been unlawfully excluded."15 In the context of jury selection, it may well be the case that most citizens are fungible. The standards for selection are not so rigorous that a large group of individuals is likely to be found to be incompetent to serve.

13. Jefferson v. Hackney, 406 U.S. 535,548 (1972).

14. Hawkins v. Town of Shaw, 437 F.2d 1286 (5th Cir. 1971), aff'd en banc, 461 F.2d 1171 (5th Cir. 1972). See also United Farmworkers of Fla. Housing Project, Inc. v. City of Delray Beach, 493 F.2d 799 (5th Cir. 1974). See generally Fessler \& Haar, supra note 5; Lineberry, Mandating Urban Equality: The Distribution of Municipal Public Services, 53 TEx. L. REv. 26 (1974); Note, Equalization of Municipal Services: The Economics of Serrano and Shaw, 82 YALE L.J. 89 (1972).

15. Mayor of Phila. v. Educational Equality League, 415 U.S. 605, 620 (1974). See also Carter v. Jury Comm'n of Greene County, 396 U.S. 320 (1970); James v. Wallace, 386 F. Supp. 815 (M.D. Ala. 1974). 
to the state, it "would render suspect each difference in treatment among little need to draw distinctions on the basis of need, ability, or willingness to pay for the service. On the other hand, the selection process for administrative agencies involves wholly different considerations since there is a scarcity of opportunities and since personal characteristics play a large role in the selection process. Under such circumstances, a "naked" statistical presentation of lack of black representation will not carry the day in the absence of other indicators of racial discrimination. Finally, if there are racially innocent reasons which explain the apparent disproportionality in treatment, judicial intervention is an invitation to engage in reverse discrimination against whites. Neutral criteria must be distorted to ensure an absolute equality of outcomes by racial group. ${ }^{16}$

The use of statistical evidence, either with respect to the initial finding of a violation of law or the adoption of a remedy, is particularly problematic in the context of racial discrimination suits involving primary and secondary public schools. There is ample evidence that black students disproportionately suffer the burdens of public schooling while not sharing in its benefits in proportion to their numbers. Blacks, as a class, consistently do less well on standardized tests than whites. ${ }^{17}$ They are overrepresented in the lower ability groups in schools which track their students. ${ }^{18}$ Their drop-out rate (or push-out rate, as some critics assert) is much higher than that for whites. ${ }^{19}$ In some urban areas, they attend the oldest schools and are exposed to the least experienced teachers. ${ }^{20}$ In Texas, for example, the poorest school districts, offering the least adequate educational programs, tend to have large concentrations of black and chicano students. ${ }^{21}$

There may be some question as to whether the glass is half full or half empty, whether progress has been slow or dramatic, whether rising expectations have focused our attention on less consequential inequalities. ${ }^{22}$ But surely there can be no resistance to the fact of inequality. The problem is what significance should be attached to these numbers? Should we infer that there is an absence of equal opportunity? That racism is at work, and that our institutions have failed? Or should the blame be cast on the black

16. Fiss, The Fate of an Idea Whose Time Has Come: Antidiscrimination Law in the Second Decade After Brown v. Board of Educ., 4l U. ChI. L. Rev. 742, 763 (1974).

17. U.S. Office of Education, Dep't of Health, Education, and Welfare, Study of The Achievement of Our Nation's Students 27 (1973); C. Jencks, INequality 81 (1972).

18. See D. Kirp \& M. Yudof, Educational. Policy and the Law $657-73$ (1974) [hereinafter cited as Educational Policy and the Law]; Kirp, Schools as Sorters: The Constitutional and Policy Implications of Student Classification, 121 U. PA. L. REv. 705 (1973).

19. See C. Jencks, supra note 17; Childrex's Defense Fund of the Washington Research Project, lic., Children Out of School in America ch. 2 (1974) [hereinafter cited as Children OUt of School].

20. See, e.g., Hobson v. Hansen, 269 F. Supp. 401 (D.D.C. 1967), aff'd en banc sub nom. Smuck v. Hobson, 408 F.2d 175 (D.C. Cir. 1969).

21. San Antonio Independent School Dist. v. Rodriguez. 411 U.S. 1.15 n.38 (1973).

22. See generally Glazer, The Limits of Social Policy, in Commentary 52 (Sept. 1971). 
students themselves for being incapable or unwilling to seize the opportunities afforded them? Does not the allocation of such blame to blacks contain the seeds of a new racism, grounded in genetic or cultural fatalism? Ultimately, we must ask: What can we say about the fairness of the processes by which rewards and punishments are distributed in the public schools by virtue of the existence of inequalities in the outcomes of those processes? ${ }^{23}$ There are those who would urge that fairness, defined in terms of need, motivation, and competence, must be discarded in favor of a system of measured equality of outcomes between racial groups. ${ }^{24} \mathrm{But}$, despite a recent intellectual push in that direction, ${ }^{25}$ there appears to be no societal consensus to abandon the liberal concept of distributive justice. ${ }^{26}$

The probative value of statistical evidence of inequalities between the races in the public schools is at the heart of the dilemma posed by the subject of this article, the suspension and expulsion of black students from recently desegregated elementary and secondary schools. The fact is that in many desegregated school systems blacks are excluded from the schools far more often than whites. ${ }^{27}$ The phenomenon is largely limited to secondary schools since roughly ninety per cent of all suspensions are imposed on children between the ages of twelve and seventeen. ${ }^{28}$ Many of those who are suspended once find themselves suspended again and again. Even where a black youngster is not permanently expelled, suspension may lead to the decision by the student, in a sense voluntary but against the background of his prior difficulties with school authorities, to drop out of school. ${ }^{29}$ Inevitably, the existence of this phenomenon has led to a search to identify the causes of black exclusion, ${ }^{30}$ and just as inevitably, the matter has wound its way to the federal courts for resolution. ${ }^{31}$

23. See generally C. JENCKs, supra note 17.

24. Id. at 8-11. See generally Yudof, Equal Educational Opportunity and the Courts, 51 TEx. L. REV. 411, 420-22 (1973).

25. See J. Rawls, A Theory of Justice (1971). But see Simson, Another View of Rawls's Theory of Justice, 23 EMORY L.J. 473, 491 (1974).

26. See Nisbet, The Pursuit of Equality, 35 Pub. Interest 103 (Spring 1974); Bell, On Meritocracy and Equality, 29 Pub. INTEREST 29 (Fall 1972).

27. See, e.g., Southern Regional Council and the Robert F. Kennedy Memorial, The Student Pushout: Victim of Continued Resistance to Desegregation 6 (1974) [hereinafter cited as Student Pushout Report]; Children Out of School ch. 2.

28. Childrex Out of School 126.

29. Cf. Madera v. Board of Educ, 267 F. Supp. 356, 371 (S.D.N.Y. 1967), rev'd on other grounds, 386 F.2d 778 (2d Cir. 1967).

30. See Student Pushout Report 17-22; Children Out of School.

31. See United States v. Wilcox County Bd. of Educ,, 494 F.2d 575 (5th Cir. 1974); Floyd v. Trice, 490 F.2d 1154 (8th Cir. 1974); Hawkins v. Coleman, 376 F. Supp. 1330 (N.D. Tex. 1974); Rhyne v. Childs, 359 F. Supp. 1058 (N.D. Fla. 1973), aff'd sub nom. Sweet v. Childs, 507 F.2d 675 (5th Cir. 1975); Dunlap v. Charlotte-Mecklenburg Bd. of Educ., 367 F. Supp. 666 (W.D.N.C. 1973); Tillman v. Dade County School Bd., 327 F. Supp. 930 (S.D. Fla. 1971). See generally McClung, The Problem of the Due Process Exclusion: Do Schools Have a Continuing Responsibility to Educate Children With Behavior Problems?, 3 J. LAw \& EDuc. 491 (1974). 
The competing theories often advanced to explain black exclusions are volatile and less than complimentary to the actors. As David Hume sagely noted, cause and effect relations are generally established on the basis of experience and not reason. But our experiences, our perceptions of the world and views as to what is plausible, are so different. The civil rights advocate who has witnessed racial discrimination in a myriad of circumstances, who recalls George Wallace at the schoolhouse door, and who has viewed with alarm the increasing sophistication with which racism is practiced, believes that black students, once again, are the victims of racial discrimination. The first step was state-imposed separation of the races; the latest manifestation of the segregationist philosophy is state-imposed exclusion of many black students from formally integrated schools. The process of exclusion is no more benign than the process of student assignment by neighborhood. ${ }^{32}$ For the black student, removed from his community and placed early in a white dominated world, exclusion is one more example of institutional and personal hostility toward his race. He perceives a lack of evenhandedness in the application of school rules and punishments, and an inability on the part of white adults and students to understand the ways in which blacks interact with each other. They are puzzled that conduct which they view as perfectly normal is perceived as threatening and detrimental to order and learning by school officials. ${ }^{33}$ They often respond by not cooperating: "'No way I'm going to do things the Man's way." "34 For white students, blacks may appear to be the less serious students, isolated from the "mainstream," who occasionally threaten or intimidate them. Extortion of money and other conduct deemed threatening is commonplace, and they view school officials as protecting their safety. The experienced white administrators and teachers-however understanding they may try to be of the institutional and structural factors within schools and the black community which may explain the behavior of black youngsters-indicate that there is a minority among black students who are troublemakers. These troublemakers engage in actions which are seen as physically threatening and disruptive of authority relationships within the school. In their view, black overrepresentation among those suspended or expelled is simply incident to the fair administration of essential school rules designed to safeguard the integrity of the teaching and learning environment. ${ }^{35}$

While the evidence supporting the various theories is sketchy at best, it seems likely that the causes of black exclusion are complex and interrelated, and that the application of any single theory exaggerates and distorts

\footnotetext{
32. See Student Pushout Report 19-22.

33. Id. at $12-16$.

34. Elsner, A Problem at Evanston High, The Wall Street Journal, April 16, 1974, at 22, col. 4.

35. See, e.g., Colen, Black Pupils' Suspensions Up in County, The Washington Post, Sept. 29, 1974, at A-1, col. 1 .
} 
reality. But the significance of the simplification of causes of black suspension and expulsion is this: the factual reasons for the phenomenon have been thought to be dispositive with respect to the assignment of legal responsibility and ultimately the formulation of remedies. If racism is the moving cause, then there is a violation of the fourteenth amendment. If the misconduct of black students is the moving cause, then no action for redress will lie. This approach is troublesome. First, by casting the problem in terms of a dichotomy of blame, litigants compel the courts to brand either school officials or black students as lawless. Individual responsibility becomes paramount when institutional factors, inherent in schools and in the desegregation process, may be more decisive. There is growing evidence that the structure of schooling is more important to the success of integration than the simple mixing of bodies. ${ }^{36}$ Moreover, the courts, and justifiably so, may be reluctant to brand a whole school system and its staff and teachers as racist, preferring instead to perceive exclusion as incidental to the enforcement of necessary rules. Second, while proportionately, minorities suffer from the exclusion penalty more than whites, suspension and expulsion are not confined to any single segment of the school population. There are many whites, and particularly, one suspects, poor whites, whose educational careers are ruined by the imposition of such sanctions.

The false dialectic of racism versus blacks as uneducable ruffians also misses the real problem. Students often are suspended and expelled for trivial violations of the hidden curriculum; that is, the rules with respect to obedience to authority, adherence to time schedules, silence, and the like. ${ }^{37}$ The penalty often is excessively punitive in light of the infraction. Whatever the merits of existing patterns of school governance and institutional rules, the fact is that school authorities often deal with relatively minor infractions with the heavy-handed sanction of exclusion. In addition, even where the offense significantly disrupts the school or endangers life and property, the official response is simply to give up on the child. The truth is that many school systems have not learned to deal with behavior problems, and their only response is the age-old one: banishment from the institution. Many children, indeed, may not belong in regular classes, but this does not mean that they may be denied any state-provided education. School systems must learn to deal more flexibly with student behavior problems: they must be more institutionally adaptive, and thus more considerate of the educational interests of their charges. Exclusion solves problems for

36. See, e.g., Cohen, Modifying the Effects of Social Structure, 16 Am. Behavioral. Scientist 861 (1973); Cohen \& Roper, Modification of Interracial Interaction Disability: An Application of Status Characteristic Theory, 37 Ам. Soc. REv. 643 (1972).

37. Student Pushout Report 12; Children Out of School 120. See generally P. Jackson, Life in Classrooms (1968); H. Kohl, 36 Children (1967); C. Silberman, Crisis in the CilassROOM ch. 4 (1970). 
teachers and administrators but only at the expense of those who look to the school as a mechanism for social and economic advancement. This is all the more problematic when it occurs in a desegregation context, thwarting the very expectations which are central to the integrationist ethic.

The basic premise of this article then is that school authorities should be held accountable for the educational welfare of their students. They should be responsible for educating them, and this means that exclusion from a school should be an extraordinary remedy employed only when other sanctions are unavailing or when the safety of persons and property demands. Even under these circumstances, school systems are obliged to provide the child with some reasonable level of educational services. Placement in vocational programs, home tutoring, and the like may be in order. This conclusion is not dependent on the allocation of blame among administrators, teachers, and students; rather, it proceeds from the assumption that public educators bear responsibility for students even if the source of difficulty is not of their own making. Nor does it require the passing of judgment on the rightness of school rules and the debate over the cultural biases of the modern public school. The focus is on the magnitude of the punishments imposed on students.

With this as a background, Part I of the article provides a more detailed examination of the many reasons for black exclusion, concluding that the search for blame is not likely to be fruitful and avoids consideration of the impact of suspension and exclusion on children. Part II examines the constitutional and policy framework for addressing black exclusion, suggesting the lines of legal analysis which might support a limitation on the power to exclude.

\section{I}

The Facts of Black Exclusion:

Unanswered Questions and Tentative Theories

The exclusion of black students from the public schools has only recently undergone intensive public scrutiny, and it is only in the last two years that researchers have begun the process of data collection to determine the extent of the problem. ${ }^{38}$ This apparent insensitivity is a function of a number of legal, political, and educational factors. Most prominent among them is the hallowed position traditionally occupied by the public educational enterprise in American society; historically, schools were insulated from the type of public oversight regularly afforded other institutions. The "great school legend," the bundle of unproven assumptions about the efficacy of

38. See Statement of Peter E. Holmes, Director, Office of Civil Rights, Department of Health, Education, and Welfare. in Hearings on H.R. 6265 Before the Subcommittee on Equal Opportunities of the House Committer on Education and Labor. 93d Cong., 2d Sess., 747 (1974). 
public schooling and its relation to the good life, had placed it on a pedestal with only occasional sniping by the dissatisfied. ${ }^{39}$ Schooling decisions were for "professionals" and "politicization" of the process must be resisted.40 Since the Brown decision ${ }^{41}$ in 1954 and the Coleman Report ${ }^{42}$ and other investigations of the effectiveness of schools $^{43}$ in the last decade, the imperviousness of public schooling to criticism has crumbled. That schools were long on promise and short on performance was suddenly revealed. ${ }^{44}$ Legal and political efforts, first directed against system-wide segregation and funding inequalities, inevitably turned to what occurs within individual schools. Ability grouping, ${ }^{45}$ bilingual education, ${ }^{46}$ special education, ${ }^{47}$ and now student exclusion ${ }^{48}$ have become targets for reform and litigation. This trend was sharply reinforced by the Supreme Court's landmark decision in

39. See C. Greer, The Great School Legend (1972).

40. See generally R. Callahan, Education and the Cult of Efficiency (1962).

41. Brown v. Board of Educ., 347 U.S. 483 (1954).

42. J. Coleman, Equality of Educational Opportunity (1966).

43. See, e.g., On Equality of Educational Opporitunity (F. Mosteller \& D. Moynihan eds. 1972); Rand Corporation, How Effective is Schooling (1972); J. Guthrie, G. Kleindorfer, H. Levin, \& R. Stout, SChool.s aNd INequality (1971).

44. See J. Coleman, supra note 42; J. Guthrie, G. Kleindorfer, H. Levin, \& R. Stout, supra note 43; The Solution as Part of the Problem (C. Greer ed. 1973); C. Greer, supra note 39; C. Silberman, supra note 37.

45. See McNeal v. Tate County School Dist., 508 F.2d 1017 (5th Cir. 1975); Hobson v. Hansen, 269 F. Supp. 401 (D.D.C. 1967), aff'd en banc sub nom. Smuck v. Hobson, 408 F.2d 175 (D.C. Cir. 1969). See generally Kirp, supra note 18; Sorgen, Testing and Tracking in Public Schools, 24 HAST. L.J. 1129 (1973); Note, Legal Implications of the Use of Standardized Ability Tests in Employment and Education, 68 Colum. L. Rev. 691 (1968).

46. See Lau v. Nichols, 414 U.S. 563 (1974); Serna v. Portales Municipal Schools, 499 F.2d 1147 (10th Cir. 1974). See generally T. Anderson \& M. Boyer, Bilingual Schooling in The UNited States (1970); Johnson, The Constitutional Right of Bilingual Children to an Equal Educational Opportunity, 47 S. CAL. L. Rev. 943 (1974); Sugarman \& Widess, Equal Protection for Non-English Speaking School Children: Lau v. Nichols, 62 Calif. L. Rev. 157 (1974); Grubb, Breaking the Language Barrier: The Right to Bilingual Education, 9 Harv. Civ. Rights-Civ. LiB. L. Rev. 52 (1974); Montoya, Bilingual-Bicultural Education: Making Equal Educational Opportunities Available to Natural Origin Minority Students, 61 GEo. L.J. 991 (1973); Kobrick, A Model Act Providing for Transitional Bilingual Education Programs in Public Schools, 9 Harv. J. LeGIS. 260 (1972).

47. See Nickerson v. Thomson, 504 F.2d 813 (7th Cir. 1974); Larry P. v. Riles, 343 F. Supp. 1306 (N.D. Cal. 1972); McMillan v. Board of Educ., 430 F.2d 1145 (2d Cir. 1970). See generally Kirp, supra note 18; Sorgen, supra note 45; Herr, Retarded Children and the Law: Enforcing the Constitutional Rights of the Mentally Retarded, 23 Syr. L. Rev. 995 (1972); Note, The Right to Education for Mentally Retarded Children, 43 U.Mo.K.C.L. REv. 79 (1974).

48. See Mills v. Board of Educ., 348 F. Supp. 866 (D.D.C. 1972); Pennsylvania Ass'n for Retarded Children v. Commonwealth, 334 F. Supp. 1257 (E.D. Pa. 1971), 343 F. Supp. 279 (E.D. Pa. 1972) (consent order); Hosier v. Evans, 314 F. Supp. 316 (D.V.I. 1970); Knight v. Board of Educ., 48 F.R.D. 115 (E.D.N.Y. 1969). See generally Van Geel, Does the Constitution Establish a Right to an Education, 82 SCHOol Rev. 293 (1974); Herr, supra note 47; Dimond, The Constitutional Right to Education: The Quiet Revolution, 2 Hast. L.J. 1087 (1973); J. Regal, R. Elliot, H. Grossman, \& W. Morse, The Systematic Exclusion of Children From School (1971). The extent that due process protections must accompany a suspension or expulsion decision has also received extensive judicial treatment. See, e.g., Goss v. Lopez, 419 U.S. 565 (1975). 
Tinker v. Des Moines Independent Community School District ${ }^{49}$ in 1969 in which it was held that federal courts were empowered to overturn school discipline decisions for constitutional infirmity. It has further been accelerated by the realization that the physical mixing of bodies is merely the beginning of the desegregation process, and that many changes in the school environment must occur if the humanistic aims of school desegregation are to be realized.

Interest in the black exclusion problem has been manifested by a number of studies recently undertaken by several private civil rights groups, ${ }^{\mathbf{5 0}}$ which in provocative and groundbreaking reports, have catalogued the dimensions of the problem with Nader-like zeal. ${ }^{51}$ The essential conclusion of these studies of black exclusion is that black students in public schools are suspended or expelled in numbers more than twice their proportion of the school population. Exclusion from schooling, like academic success, is not randomly distributed between identifiable racial groups. Figures from specific school districts abundantly support this assertion. For example, blacks make up twenty-eight per cent of the high school population and thirty-five per cent of the junior high school population in Little Rock, Arkansas, and yet nearly two-thirds of those suspended are black. ${ }^{52}$ Similar findings are reported for New Orleans, Columbus (Georgia), CharlotteMecklenburg County, St. Petersburg, and other recently desegregated southern school systems. ${ }^{53}$ The dubious distinction award for the most black exclusions, however, must go to the Dallas Independent School District, where, in a recent year, officials suspended more than six thousand minority youngsters or nearly ten per cent of the black school population. ${ }^{\mathbf{5 4}}$ These

49. 393 U.S. 503 (1969). See generally Educational. Policy and the Law 134-90; Denno, Mary Beth Tinker Takes the Constitution to School, 38 Fordham L. Rev. 35 (1969); Goldstein, Reflections on Developing Trends in the Law of Student Rights, 118 U. PA. L. Rev. 612 (1970); Nahmod, Beyond Tinker: The High School as an Educational Public Forum, 5 Harv. Civ. Righrs-Civ. Lib. L. REv. 278 (1970).

50. See, for example, Student Pushout Report and Children Out of School. These studies largely rely upon data collected by the Office of Civil Rights (OCR) of the Department of Health, Education, and Welfare in the fall of 1973. As part of its National School Survey of Public Elementary and Secondary Schools, OCR surveyed almost 3,000 school districts, accounting for over 50 per cent of the total enrollment in American public schools and about 90 per cent of all minority students. Brief for Children's Defense Fund of the Washington Research Project, Inc. and The American Friends Service Committee as Amici Curiae at 20, Goss v. Lopez, 419 U.S. 565 (1975). School districts were asked to reveal the total number of students suspended and expelled during the academic year, the cumulative number of suspension days out of school, and the racial and ethnic breakdowns of those figures. While the OCR has not completed its analysis of this data or issued any report, the private groups have relied upon its data to butress their conclusion that blacks have been the victims of institutional and personal racism in their treatment by school authorities.

51. See note 50 supra. See also S. Browning, Racially Discriminatory Suspensions in the Akron Public Schools: A Tentative Analysis, Oct. 2, 1974 (unpublished memorandum at Lawyers Committee for Civil Rights Under Law, Washington, D.C.).

52. Student Pushout Report 2.

53. Student Pushout Report 2-6. See generally Children Out of School 124-34.

54. Student Pushout Report 4; see Hawkins v. Coleman, 376 F. Supp. 1330 (N.D. Tex. 1974). 
statistics exclude expulsions, a category which presumably would have swelled the totals even higher. There are also many examples from the North, from school districts which are in various stages of desegregation. ${ }^{55}$ For example, the Lawyers' Committee for Civil Rights found that in Akron, Ohio, more than two-thirds of all schools reporting admitted that "their percentage of minority students suspended is greater than the percentage of white students suspended." 56

Apart from the crude statistics on the scope of the exclusion problem within school districts, what do we know about the incidence and process of exclusion? Precious little. We know that blacks are suspended more repeatedly than whites, if not longer. ${ }^{57}$ We know that, at least in some school districts, black students fall victim to exclusion more often than other racial and ethnic minorities. ${ }^{58}$ Finally, there appears to be a general pattern which reveals that the problem is of a greater magnitude in small cities and rural areas than in populous urban areas. ${ }^{59}$ There are, however, as Dallas and New Orleans exemplify, notable exceptions to this generalization. What we do not know, or what is known only on the basis of anecdotes which may or may not evidence more universal patterns, is far greater. The disproportionate exclusion of black students from the public schools is far from a universal phenomenon, ${ }^{60}$ and there are great unexplained variations between school districts and indeed from school to school within school districts. ${ }^{61}$ What accounts for these differences? Is it the attitudes of school officials? Are there variations in the characteristics of the black population between different geographic areas? Are there institutional factors which vary? What kinds of behavior by black students trigger the application of severe, exclusionary penalties? The raw statistics on exclusion of black students, standing alone, tell us very little about the reasons for their high rate of exclusion, and clearly are not determinative with respect to the existence of discrimination. ${ }^{62}$

There are a number of factors which would appear capable of explaining school expulsions and suspensions of black students. The most obvious of these is the educational philosophy and imagination of school administrators and teachers. Banishment, over the years, has been a controversial if typical manner of dealing with behavior problems in the schools. School systems recently have explored other means of dealing with assertedly dis-

\footnotetext{
55. Childrex OUT of School 124-34; S. Browning, supra note 51.

56. S. Browning, supra note 51 , at 1 .

57. Childrex OUT OF SCHOOL 132.

58. See Student Pushout Report 4.

59. Id. at 6 .

60. Id. at 11: Childeren Out of School 130

61. See, e.g., Hawkins v. Coleman, 376 F. Supp. 1330, 1334 (N.D. Tex. 1974).

62. See Statement of Peter E. Holmes, supra note 38, at 5-6; Student Pushout Report 10; Cihildren Out of School 149-50.
} 
obedient students. Special classes or schools, isolation for a temporary period of time, corporal punishment, referrals to police authorities, deprivation of privileges, more schooling (detentions): all of these are alternative means of handling disciplinary problems which school officials employ. ${ }^{63}$

While doubtless many of these approaches do not generate universal enthusiasm-some within-school punishments may be more injurious and stigmatizing than suspension-it seems reasonable to believe that there is great diversity among superintendents, principals, and teachers with respect to their willingness to utilize particular punishments. "Law and order" is just as much a topic of debate among educators as in the public at large. In addition, there are probably variations in resources available-for example, special facilities and teaching skills-to individual schools and school districts, and thus some administrators may have the luxury, which others do not have, of considering other options. Thus, one way to account for the variations in exclusion practices is to focus on the increasing diversification of punishment and remedial approaches to student misbehavior.

Second, there may be more racial prejudice in some school districts than in others. Possibly such prejudice is more rampant in rural areas, thereby accounting for one of the few pieces of hard evidence in the studies. Administrators and teachers in some areas may feel public pressure to deal firmly and decisively with black students and to exclude them at the first sign of trouble. Possibly these areas attract and retain teachers who are less sympathetic to black youngsters. The context may also be important. In a district in the throes of desegregation, intemperate decisions, which would be rejected in calmer times, may be reached. ${ }^{64}$ The history of interracial cooperation, or lack of it, within the community may be decisive. Moreover, as in any professional group, there are likely to be at least a few "bad apples" within school districts, teachers and principals who are racially prejudiced against blacks. This may account for the fact that within high exclusion districts, usually only a few schools, with student bodies which appear to be virtually indistinguishable from others, are responsible for the bulk of school exclusions. By its very nature, personal racial prejudice of this sort is difficult to prove since rarely will school officials admit of its existence, and there are always superficially neutral reasons which may be proferred to explain exclusions. In addition, as in many areas of debate over race policy, it may be difficult to disentangle a "law and order" philosophy of school punishments from a less defensible policy of racial discrimination.

Third, the behavioral characteristics of black students in different areas may not be uniform, and this would also help to explain the variations in exclusion rates. There may be differences between urban black children,

63. See generally S. Goldstein, Law and Public Education ch. 7 (1974).

64. See Studext Pushout Report 10. 
living in ghetto neighborhoods, and rural black children, with respect to their attitudes toward school authorities and their white peers. Some black populations are more affluent than others. Blacks bused from their neighborhoods and brought to a strange, middle-class environment may react with hostility. Both social dislocation and crimes of violence are more common among ghettoized blacks, and there is no reason to believe that the public schools are insulated from these social facts of life. ${ }^{65}$

Finally, and this is the most critical point, perceptions vary as to what constitutes behavior sufficiently threatening to the order of the school to trigger the application of severe sanctions. ${ }^{66}$ To be sure, there are many black suspensions and expulsions for fighting, threatening white students, possession of dangerous weapons, and using or selling dangerous drugs or alcohol. There is little disagreement about the need for discipline in such cases-including removal from the school building. But I suspect that the vast majority of blacks excluded have not engaged in such behavior. Rather, they are more often suspended for smoking, habitual tardiness, speaking back to teachers, truancy, noisiness, and the like. ${ }^{67}$ In short, they have assertedly engaged in institutionally inappropriate behavior, disregarding the "hidden curriculum" or values underlying institutional public schooling. When a black student or parent refers to "institutional racism," he is making reference to these institutional rules. He is arguing, in effect, that the institution has an obligation to alter its rules to make them less arbitrary and more consistent with the behavior patterns among blacks. An institution which consciously applies rules which systematically disfavor blacks is a "racist institution." On the other hand, when a white student or parent argues for the need for discipline, he is implicitly sanctioning the system of institutional rules, and maintaining that black children must learn to adapt to that system.

This theory of black exclusion is plausible, but the evidence supporting it is sketchy and anecdotal. It appears to have particular force as an explanation of exclusion in recently desegregated school systems. While we do not have statistically accurate measures of the rate of exclusion in all black schools before integration took hold, it seems likely that it is not so much that black behavior has changed radically as it is that reactions of school officials in desegregated schools, including the rigidity of application of rules and the choice of punishments, have changed. The black student is bused from his formerly all black, neighborhood school, and finds himself in a predominantly white, middle-class environment. Lacking friends in the white com-

65. See generally G. Levy, Ghetto School (1970).

66. See Statement of Peter E. Holmes, supra note 38, at 8; J. Regal, R. Filio', H. Grossman, \& W. Morse, The Systematic Exclusion of Children From School 14 (1971). See generally McClung, supra note 31 , at $517-18$.

67. See Student Pushout Report 12; Children Out of School 120. See generally Dixwell Legal Rights Foundation, Report on School Suspensions in New Haven, in S. Goldstein, LAw AND Public Education 445 (1974). 
munity, the black students tend to stick together and build their own subculture within the school. One foundation of their sub-culture is their attitude toward authority: ${ }^{68}$

Whites may be more accustomed to an authoritarian atmosphere . . . When a white student is told by a teacher to do something, he is accustomed to doing it without asking why, while the black pupil often challenged the teacher's authority and got in trouble for it.

They also may view with disdain the careful scheduling and attention to time which is so much a part of public education: ${ }^{\mathbf{6 9}}$

"When desegregation first occurred at the secondary level. . . blacks were put into a predominantly white setting where there were entirely different attitudes toward schedules, promptness and so on. The segregated schools which black students had been attending were not as oriented toward time schedules. . . Tardiness was a major violation.

"The black students got the idea that the regulations had been instituted to persecute blacks. It took a couple of years for them to realize that the rules had existed before and for them to adapt to the stricter regulations."

If the failure to adhere to institutional rules relating to respect for authority and timeliness is the primary cause of black exclusions, then we can gain a number of additional insights into the process. At the heart of the problem lies the controversy, which has plagued thinkers since Plato, of the appropriate role of the state in socializing children to values endorsed by those who control education. The problem is inherently cultural. As Professor Bowles and others have pointed out, socialization to such values as the need for decorum, delayed gratification, obedience to authority, and punctuality are closely related to the demands that an industrialized society makes on its citizens in the work force. ${ }^{70}$ Black children are subjected, like white children, to a system of rewards and punishments which furthers these values of the industrial society. While, as some have charged, the traditional values of institutional schooling may be more rigidly enforced in black or integrated schools than in white, middle class schools, ${ }^{71}$ variation seems more likely at the fringes of the hidden curriculum-open classrooms, flexible curricula, and more class discussion. It seems implausible that core institutional guidelines relating to decorum, obedience, and punctuality vary all that significantly.

68. Student Pushout Report 20.

69. Id. at 18

70. Bowles, Understanding Unequal Economic Opportunity, 63 Aм. Econ. Rev. 346 (1973). See also Behn, Carnoy, Carter, Crain, \& Levin, School is Bad; Work is Worse, 83 School Rrv. 49 (1974); Bowles, Unequal Education and the Reproduction of the Social Division of Labor, in ScHooling IN A Corporate Society 36 (M. Carnoy ed. 1972); Gintis, Education, Technology, and the Characteristics of Worker Productivity, 61 Am. Econ. Rev. 266 (1971): Gintis, Touard a Political Ecomomy of Education: A Radical Critique of Ivan Illich's Deschooling Society, in After Deschooling. What: 29 (A. Gartner, C. Greer, \& F. Riessman eds. 1973).

71. Behn, Carnoy. Carter. Crain. \& Levin. supre note 70, at 57. 
The exclusion problem also reminds us, if we needed reminding, that socialization in the public schools is accomplished as much or more through patterns of institutional governance as it is by what is directly taught in the classroom. ${ }^{72}$ It is noteworthy that blacks, like whites, are more frequently punished for violations of the so-called hidden curriculum than they are for academic failure. Furthermore, exclusion brings forth the whole debate about appropriate pedogogy in the public schools. At least since the time of Dewey $^{73}$ and Counts, ${ }^{74}$ educators have argued over the degree of order necessary to accomplish educational objectives. Most teachers and school administrators, in effect, have taken the position that a high degree of order, obedience, and punctuality is necessary to further learning. Others, including the John Holts and George Dennisons of the world, would argue that public schools are too rigid and highly structured to maximize learning. ${ }^{75}$ At present, controversy over black exclusion is simply another level at which this debate is continued.

Black exclusion also may be less of a race than a poverty problem. The types of anti-institutional behavior ascribed to blacks is commonly ascribed to many low income groups. ${ }^{76}$ The data thus far accumulated are not broken down into income categories. This would indicate, once again, that social science has failed to disentangle the variables of race and wealth. This insight is critical since it indicates that legal rules and remedies geared exclusively to racial disparities may well miss the mark since poor whites are as much victimized by suspension and expulsion as blacks. Even more significantly, it may illuminate the reasons why a disproportionate number of blacks fall victim to institutional rules in schools. Poverty is more prevalent among blacks, and the culture of the poor, emanating from the need to survive despite tremendous deprivations, may be inconsistent with the culture of schools: ${ }^{77}$

[S]ome poor children withdraw from school simply because they are poor; they are 100 hungry in the morning to make their way to school or they cannot keep up with their schoolwork because ther must travel so far with

72. See. e.g. S. Sarason. The cleture of the School and the Problem of Change (1971); Bowles \& Gintis. IQ in the Class Structure. 3 SOCIAL POLICY 65 (1972); Raskin. The Channeling Colonv. in Schooling in a Corporate Society 23 (M. Camoy ed. 1972): Jackson, Student's Wonld, 66 Flem. SChool J. 345 (1966). See also note 37 supra.

73. See J. Dewey, Democracy and Education (1916).

74. See G. Counts, The American Road to Culture (1930).

75. See, e.g., G. Dexison, The Lives of Childrex (1969): E. Frledenberg. Coming of Age in America (1965); P. Goodman, The Communty of Scholars and Compulsory Miseducation (1966); J. Holt, The Underachieving, School (1969); C. Silberman, Crisis in the ClassROOM (1970).

76. Childrex Uet of School. $134-35$

77. Coule, Dying a Differem Sort of Death: The Exclusion of Children From School, 83 ScHool Rev. 145, 148 (1974). See generally ChundeN OLT of School 78-89. I prefer this formulation of the problem to the more stigmatizing and obfuscating phrase "behaviorally handicapped." See McClung, supra note 31 , at $511-15$. 
inadequate transportation. They are lucky to make it to school one or two days a week. These are children who work inside as well as outside their homes.

. . . Many poor children who do not hold jobs, who do have enough food, and who sleep well enough at night nevertheless cannot face the environment of school because they are ashamed of what we would call their "station in life." They dread being seen in the same shoes or dresses day after day. They fear the moment. . . when a well-meaning teacher may ask them about their background, their parents and grandparents, their home, their neighborhood....

As is so often the case, the public schools mirror the problems of the larger community, neither isolating the students from those problems nor measurably aiding in their resolution.

Finally, all of these observations indicate that the problem of black exclusion from the public schools is complex, and that approaches premised on simplistic notions of personal or institutional racism are just that-simplistic. I venture to guess that if all the racist teachers and principals in the nation were magically removed from their positions of public trust, exclusion would still be very much with us-and it would still disproportionately affect blacks. Similarly, simply labeling the public schools as racist institutions does a grave injustice; for it fails to analyze the legitimacy of the socialization process, and the values inherent in that process, in the public schools. Unequal results do not necessarily reflect unfair rules and procedures.

Where does all this lead us? What is an appropriate response? By rejecting the theory that black exclusion is a manifestation of racial discrimination, we seem to have traveled from the barely manageable conundrums posed by Brown and its progeny to the unspeakable intellectual horrors of value transmission and the allocation of power between child, family, and state. The neglected web of Pierce ${ }^{78}$ and Meyer ${ }^{79}$ and Farrington ${ }^{80}$ need be revisited, as well as $Y_{o d e r}{ }^{81}$ and Barnette. ${ }^{82}$ I have no doubt that these issues deserve careful attention; for legal scholars have for too long overlooked the role of the state as a communicator, a communicator with vast power to influence behavior, attitudes, and ultimately political decisions. This is particularly acute in the public schools, given the captive audience status and immaturity of the students. But candor requires the admission that the nature of the socialization process in relation to black exclusion is such as to make it an unlikely judicial avenue for reaching the latter. The values which are not honored and which trigger exclusion emanate from the nature of

78. Pierce v. Society of Sisters, 268 U.S. 510 (1925). See generally Educational. Policy AND THE LAW $1-10$.

79. Meyer v. Nebraska, 262 U.S. 390 (1923).

80. Farrington v. Tokushige, 273 U.S. 284 (1927).

81. Wisconsin v. Yoder. 406 U.S. 205 (1972).

82. West Virginia State Bd. of Educ. v. Barnette, 319 U.S. 624 (1943). See Note, Freedom and Public Education: The Need for New Standards, 50 Notre Dame Lawyer 530 (1975). 
the institutional environment of the modern public school: the need to educate large numbers of students in a specialized institution, which is operated in hierarchical fashion by a professional bureaucracy. ${ }^{83}$ More importantly, if these institutional values are to be destroyed, then either the institutions must be destroyed, or they must be so reconstructed that they bear little resemblance to what today we describe as a public school. While certainly some accomodation between competing value systems is possible, this more far-reaching result is unlikely. Specialized educational institutions, operated by government, appear to be a near universal fact of life in modern nations. They will not soon disappear in any society dedicated to technological development, industrialization, and the specialization of labor ${ }^{84}$ The demise of traditional, mediating institutions as vehicles for transmitting culture and skills, the necessity to delegate responsibility for education to a fraction of all adults, and the need to communicate so much, so quickly, all argue against a return to non-institutional educational systems. As C. Wright Mills has noted, the means of communication "have paralleled in range and efficiency the other institutions of greater scale that make up the modern society of masses." 85

In the present context, it is also difficult to imagine an agency less willing or able to undertake a program of structural reform of the public schools than the courts. Whatever their ability, largely untested, to scrutinize direct indoctrination in the classroom, it would appear far more difficult to order substantial changes in patterns of institutional governance to obliterate objectional values. Moreover, as products of the public schools themselves, it appears unlikely that judges would seriously challenge the institutional values underlying public schooling. And if they seriously undertook such an analysis, they might well approve the transmission of values so closely related to the needs of industrial society.

II

Policy and Constitutional Framework

\section{A. Policy}

If the black exclusion problem is not a manifestation of racial discrimination, as that phrase is typically understood, the whole panoply of legal doc-

83. See Green, Schools as Communities, 39 HaRv. Ed. Rev. 221 (1969). See generally C. SiLBerman, supra note 37; W. Waller, The Sociology of Teaching (1965).

84. See, e.g., I. Illich, Deschooling Society (1971); P. Coombs, The World Educational Crisis: A Systems Analysis (1968); J. Vaizey, Education for Tomorrow (1966); Green, supra note 83; Bowles, Understanding Unequal Economic Opportunity, 63 AM. ECon. Rev. 346 (1973); Bowles, Education and Socialist Man in Cuba, in Schooling in a Corporate Society 272 (M. Carnoy ed. 1972).

85. Mills, Mass Society and Liberal Education, in Power, Politics, and People: The Collected Essays of C. Wright Mills 353, 361 (I. Horowitz ed. 1963). 
trines associated with racial classifications is not applicable. The substantive rules which lead to exclusion in disproportionate numbers by race appear to have a racially neutral justification and purpose. While those substantive rules may be subject to attack as seeking to bring an unconstitutional orthodoxy to the public schools, everything we know about education in the modern industrial state argues against such a conclusion. In weighing the difficulties of accomplishing mass educational objectives against the incidental losses to individual decision-making wrought by institutionalized learning, the choice in favor of the latter is virtually inescapable. But there is a third level at which the problem of black suspension and expulsion may be approached. Even if school rules are nondiscriminatory and are sufficiently related to the educational process, we may appropriately inquire as to the gravity of the punishments imposed and the nexus between violations and those punishments.

While the courts often eschew reliance on notions of the reasonableness of punishments either absolutely or in relation to the wrongs committed, this is, at bottom, the issue presented by black exclusion. Black students, whose only offense, at best, may be a failure to adhere to the school schedule or to obey instructions promptly and respectfully, find themselves completely banished from the state's educational system. This is the age-old response of total and semi-total institutions which have not learned to deal with even the most minor threats to the institution. It is akin to a dishonorable discharge from the armed services or isolation of inmates in prisons. For a student who is consistently late to class or truant, it is bizarre to visit the penalty of complete exclusion upon him. ${ }^{86}$ A student's failure to attend all classes results in a state-imposed requirement that he attend none. From the institution's perspective, however, there is great gain in ridding itself of a troublemaker who will not comply with the rules, who is perceived as a threat to authority, and who may set an example for others to deviate from the institutional ground rules.

Lurking behind the proposition that exclusion is often an inappropriate punishment lies two suppositions which may distinguish this situation from others in which the gravity of the punishment is challenged. First, the state has an obligation to provide an education to all children where it has chosen to establish a primary and secondary educational system and to make it freely available. ${ }^{87}$ The state has assumed responsibility for the education of the young, and whatever the causes of exclusion of blacks, the state should not be permitted to shirk that responsibility. To be sure, as the Supreme Court has recently reminded $\mathrm{us}^{88}$ there may be no obligation to provide equal

86. See Dixwell Legal Righis Foundation, supra note 67.

87. See Van Geel, supra note 48; Dimond, supra note 48. See. e.g., Mills v. Board of Educ., 348

F. Supp. 866 (D.D.C. 1972); Hosier v. Evans, 314 F. Supp. 316 (D.V.I. 1970).

88. San Antonio Independent School Dist. v. Rodriguez, 411 U.S. 1 (1973). 
services or dollars or an equal educational opportunity defined in input or output terms. ${ }^{89}$ Regular classes in the public schools may not be appropriate for youngsters with behavioral problems just as they may not be appropriate for retarded or hyperkinetic children. Within a wide range of discretion, the state may make educational decisions for its charges, concluding that special schools, vocational training, home instruction, or other nontraditional forms of learning are required. But it may not completely give up on those that it has obliged itself to educate. ${ }^{90}$ All children are capable of learning, whether it be particular mechanical skills, higher mathematics, or simply sewing and cooking, and such learning may be of inestimable value in their adult lives. ${ }^{91}$ Thus institutional concerns may dictate the nature of the educational setting in which learning takes place, but it may not compel the abandonment of all educational efforts. This is particularly true in the case of the poor and minorities since rarely will they be able to afford private alternatives to public schooling. Moreover, exclusion simply does not remedy or even address the problems which may underlie the child's asserted misbehavior: ${ }^{92}$

Yet instead of giving children with problems the special attention they need, schools try to give them no attention at all.

Some children misbehave in school because they have emotional or psychological problems. Others cannot see or hear properly and may never have had the situation corrected medically. Still others may have learning disabilities. ...

There is, of course, nothing inevitable about the universality and compulsoriness of public education. The state, out of a concern for efficiency, might well decide to educate only limited numbers of children or to exclude those who in one fashion or another later prove difficult or expensive to educate. Alternatively, it might decide not to educate its children at all, leaving schooling to the private sector, and employing its scarce resources for assertedly more worthy endeavors such as welfare or police protection. My assumption, however, is that government, reflecting the views of most citizens, has already decided in its laws, budgets, and public pronouncements to treat education as a "merit" good:"93

89. But see J. Coons, W. Cuune, \& S. Sugarman, Private Wealth and Public Education (1970); Kirp, The Poor, the Schools, and Equal Protection, 38 Harv. Ed. Rev. 635 (1968); Horowitz, Unseparate But Unequal-The Emerging Fourteenth Amendment Issue in Public School Education, 13 U.C.L.A.L. Rev. 1147 (1966); Yudof, supra note 24.

90. Children Out of School 135-39. See Dimond, supra note 48; Kirp, supra note 18.

91. Yudof, supra note 24 , at 474 n. 326 and authorities cited therein.

92. Childrex Out of School 136; McClung, supra note 31, at 507.

93. Calabresi \& Melamed, Property Rules, Liability Rules, and Inalienability: One View of the Cathedral, 85 HaRv. L. REv. 1089,1100 (1972). For discussions of state intervention to secure the satisfaction of "just wants" and of other phrases describing essentially the same concept, see Baker, Utility and Rights: Two Justifications for State Action Increasing Equality, 84 Yale L.J. 39 (1974); Michelman, Foreword: On Protecting the Poor Through the Fourteenth Amendment, 83 HaRv. L. Rev. 7 (1969). 
If the choice of entitlements affects wealth distribution generally, it also affects the chances that people will obtain what have sometimes been called merit goods. Whenever a society wishes to maximize the chances that individuals will have at least a minimum endowment of certain particular goods-education, clothes, bodily integrity-the society is likely to begin by giving the individuals an entitlement to them. If the society deems such an endowment to be essential regardless of individual desires, it will, of course, make the entitlement inalienable.

Each child is entitled to an education at public expense, and that entitlement is inalienable and not normally a subject for bargain or exchange although currently school authorities have the power to extinguish that entitlement. The government might have chosen otherwise, but in fact it has not. The reasons for so treating education are numerous. First, it may be feared that the failure to provide an education may result in significant externalities. ${ }^{94}$ An uneducated person may be more likely to commit crimes or become a welfare recipient, and thus the personal decision of a parent or child (or the decision of school authorities) may adversely affect third persons who have no role in the decision-making. Second, we may fear that parents, educators, and children will make inefficient decisions in the short run, responding to particular stresses and exigencies, and that universal and compulsory education comports more with what a rational individual would choose over the long run. This argument is what Calabresi describes as the "self paternalism" justification for forbidding the sale of merit goods. ${ }^{95}$ Third, government may simply "bite the bullet" and decide that, because of its superior informational position or otherwise, individuals and society would be better off with a universal and compulsory education system from which no or few individuals were excluded. This is a straightforward argument for paternalism. ${ }^{96}$

The first three arguments for treating education as a merit good are essentially utilitarian in nature. Their premise is that such treatment will maximize the aggregate satisfaction of educational wants by correcting for inadequacies in market mechanisms which produce inefficiencies in the allocation of educational services. The last argument is rather different in character, proceeding from the assumption of a theory of right. ${ }^{97}$ The state may afford certain rights to individuals even if satisfaction in the aggregate is reduced: ${ }^{98}$

A right, in the sense Dworkin uses it, is a claim which the government would be wrong to override if the government's only grounds were that

\footnotetext{
94. Cf. Calabresi \& Melamed, supra note 93, at 1111.

95. Id. at 1113 .

96. See id. at 1113-14.

97. This distinction between utility and rights is developed in Baker, supra note 93. See also Dworkin, Taking Rights Seriously, in Is LAw DeAD? 168 (E. Rostow ed. 1971).

98. Baker, supra note 93, at 48. See also J. Rawls, A Throry of Justice (1971); Dworkin, supra note 97 .
} 
overriding the right would increase the well-being of the community as a whole. Thus, a right is a claim to have a certain need satisfied even if having this need satisfied causes a decrease in total or average utility.

In the case of education, a right to satisfaction of educational wants may emanate from a sense of obligation on society's part, ${ }^{\mathbf{9 9}}$ or, put somewhat differently, the treatment of education as a merit good may be a response to a concern for the redistribution of wealth: ${ }^{100}$

Whether an entitlement may be sold or not often affects directly who is richer and who is poorer. . . Favoring the specific group that has benefited may or may not have been the reason for the prohibition on bargaining. What is important is that, regardless of the reason for barring a contract, a group did gain from the prohibition.

The assumption then may be that the poor, due to their inability to afford private schools, their lack of information, or other factors, will be deprived of the benefits of an education unless the state creates a positive entitlement to it. Since they are entitled to such benefits under theories of distributive justice, education must be treated as a merit good. Moreover, the just distribution of education services may also be an efficient distribution, particularly if it is assumed that there are declining marginal utilities or that personal utility is partially dependent on the well-being of others. ${ }^{101}$

If it is assumed that education is a merit good, defined as a utilitarian concept, the question, in the present context, must be whether or not school exclusion policies are likely to maximize its consumption. One such argument, treated below, is that temporary exclusion is more likely than other measures to increase the desire of the affected individuals to remain in school over the long run. There is little evidence to support such a supposition. A second argument is that the loss of the entitlement to education on the part of some students is more than offset by the educational gains to other students who no longer need tolerate interference with their education. Assuming that those who are denied their entitlement are in fact the same class of persons who significantly interfere with the education of others, in most cases it may be possible to prevent the interference without denying the entitlement. The rejoinder is that this may be quite expensive. At one level this may be no more than a recapitulation of the debate over whether education should be a merit good. As long as society adheres to the merit good approach to education, these added costs must be endured. Of course, government might respond by reducing the level of resources devoted to the class of children now in school and shifting those resources to the class of children now excluded. This would raise profound, if currently unanswer-

99. Baker. supra note 93. a 55.

100. Calabresi \& Melamed, supra note 93. at 1114.

101. Id. at $44-46$. 
able, questions as to which course of action would maximize the overall consumption of public and private education.

If the treatment of education as a merit good rests on the notion that individuals are entitled to some minimum level of satisfaction of their educational needs, then the implications for school exclusion policies are obvious -if somewhat tautological. School children may not be temporarily or permanently denied a public education even if such a course of action lowers the aggregate satisfaction of educational wants. But equally as important, given the fact that we do not possess definitive data allowing us to compare the efficiency of the exclusionary and nonexclusionary alternatives, and given the plausibility of the assumption that the distributive justice approach will yield efficient results, I believe that a public policy choice against exclusionary practices is entirely defensible.

The second supposition underlying the analysis is that there is a significant relationship between assertedly temporary school suspension and expulsion decisions and permanent exclusion from the public schools. ${ }^{102}$ Suspensions may range from only a few days to five or six weeks, and often expulsions, by their own terms, are not permanent, keeping the child out of school only for the remainder of the semester in which the offense took place. But the reality of the situation is far different from the limited nature of the punishment appearing on the surface. Many school districts do not allow a child to continue to receive his assignments for the period that he is excluded from the school building, nor is there an opportunity to take examinations at home. The student returns to school weeks behind his peers, and must make a tremendous personal effort to keep up with his present work while attempting to make up for lost work. For the student who, by virtue of his exclusion, may have demonstrated his failure to adjust to the demands of the public school, and who may not be a particularly serious student in the first instance, this burden may be virtually impossible to carry. He gets further and further behind in his work, and ultimately may drop out of school altogether. While this may be officially characterized as a "voluntary" decision, the reality is that it was the initial exclusion decision which triggered the "voluntary" decision to discontinue public schooling. ${ }^{103}$ Absence from the school environment may produce further estrangement from the institution. In the absence of parental and peer pressure to remain in school, the student may learn that he enjoys being out of school and that it is not worth the "hassle" to return. If he returns even temporarily, he may be so hostile and alienated that he acts out his aggressions. This, in turn, may lead to additional suspension and expulsion decisions.

102. Student Pushout Report 8; Children Out of School 119.

103. See, e.g., Madera v. Board of Educ., 667 F. Supp. 356, 369 (S.D.N.Y. 1967), revid on other grounds, 386 F.2d 778 (2d Cir. 1967). 
The point then is that individual suspension and exputsion decisions, however temporary, may effectively terminate the educational careers of those affected, thereby reducing their opportunity to enter college and obtain high status and high income employment. Even where this is not the case, exclusion is likely to affect academic performance as the student is required to double his workload on his return. And finally, exclusions are noted on the student's permanent school record, and this may independently affect his educational and employment opportunities. ${ }^{104}$ All of this suggests that suspension and expulsion should be exceptional punishments meted out only where there are serious violations of school rules, and where there is significant danger of violence, destruction of school property, or disorder. Even in those circumstances, special services should be made available to the child for the period that he is out of school, and other alternatives-counseling, placement in special classes or schools, vocational programs in private industry-should be explored before the ultimate sanction is employed. ${ }^{105}$ It is noteworthy in this regard that there appears to be little disparity between blacks and whites in terms of the level of educational expenditures while they remain in primary and secondary schools, but the overrepresentation of blacks among dropouts and pushouts leads to a lower lifetime state expenditure on blacks and whites. ${ }^{106}$

\section{B. The Judicial Response: The Racial Discrimination Approach}

Thus far, while black exclusion has lurked beneath the surface in many first and fourteenth amendment controversies in desegregating school districts, ${ }^{107}$ there have only been a few cases in which the issue has been directly confronted. ${ }^{108}$ In these relatively few decisions the federal courts have not been willing to allow the desegregation train to carry the extra baggage of student discipline problems. Unlike teacher and administrator dismissals ${ }^{109}$ and intraschool ability grouping policies, ${ }^{110}$ federal courts have tended to

104. See generally Childrex OUt of School 135-36.

105. See generally Children Out of School 10, 147-48; R.E. Phay \& J. Cummings, Student Suspensions and Expulsions 7-8 (1970); McClung, supra note 31, at 520-26; $c f$. Carrington, Civilizing University Discipline, 69 MICH. L. REv. 393 (1971).

106. C. Jencks, Inequality 26-27 (1972).

107. See, e.g., Lopez v. Williams, 372 F. Supp. 1279 (S.D. Ohio 1973), aff'd sub nom. Goss v. Lopez, 419 U.S. 565 (1975); Dunn v. Tyler Independent School Dist., 460 F.2d 137 (5th Cir. (1972).

108. Boykins v. Fairfield Bd. of Educ., 492 F.2d 697 (5th Cir. 1974); Hawkins v. Coleman, 376 F. Supp. 1330 (N.D. Tex. 1974); Rhyne v. Childs, 359 F. Supp. 1085 (N.D. Fla. 1973), aff'd sub nom. Sweet v. Childs, 507 F.2d 675 (5th Cir. 1975); Tillman v. Dade County School Bd.. 327 F. Supp. 930 (S.D. Fla. 1971).

109. See, e.g., Sparks v. Griffin, 460 F.2d 433 (5th Cir. 1972); Moore v. Board of Educ., 448 F.2d 709 (8th Cir. 1971). Compare Armstead v. Starksville Municipal Separate School Dist., 325 F. Supp. 560 (N.D. Miss. 1971), with United States v. Chesterfield County School Dist., 484 F.2d 70 (4th Cir. 1973).

110. See, e.g., McNeal v. Tate County School Dist., 508 F.2d 1017 (5th Cir. 1975); Lemon 
distinguish between present school disciplinary policies and the need to remedy past de jure discrimination practices: they have been unwilling to reverse exclusion decisions by simply invoking the remedial discretion of federal courts. Nonetheless, the courts have tended to focus exclusively and improperly, I believe, on allegations of racial discrimination. ${ }^{111}$ The result is a great confusion of legal doctrine, a bit of dishonesty with the facts, and the lack of a remedy even where black plaintiffs prevail.

The earliest case in which the disproportionate exclusion of blacks was challenged is Tillman $v$. Dade County School Board. ${ }^{112}$ In that case, the evidence showed that fighting had broken out between black and white youngsters at the South Dade High School. While in the court's view the evidence failed to reveal whether blacks or whites were initially responsible for the disruption and destruction of school property, all but six of the ninety-three students suspended were black. Many of those suspensions were lifted, leaving one white student and forty-seven black students out of school for ten or more days. School authorities explained this discrepancy by noting that their overriding concern had been to separate the black and white students. To this end, the police had moved in and pushed the white students off the campus, while containing the black students within the school building. As a result, defendants argued that only the black students were easily subject to identification and apprehension for misconduct. The court accepted the position of the defendants, attributing the disproportionality in exclusion to this "fortuitous circumstance." 113

While it is true that when figures speak courts listen, . . it is apparent from a review of all the evidence in this case that the figures alone do not tell the whole story and consequently are not determinative of this issue.

....

... The fact that Blacks were apprehended and many more Blacks than Whites suspended was nothing more than a fortuitous circumstance, a result of their physical location.

The court did not inquire as to why the decision was made to isolate black students rather than white students on the campus or as to the feasibility of identifying white students before they had departed from the campus. There appeared to be sufficient evidence of absence from regular classes (pictures were taken) to justify the suspension of each black student, and the court refused to take the matter further.

v. Bossier Parish School Bd., 444 F.2d 1400 (5th Cir. 1971); United States v. Sunflower County School Dist., 430 F.2d 839 (5th Cir. 1970). See generally Yudof, supra note 24, at 451; Kirp, supra note 18, at 763; Punke. Competence as a Basis of Student Assignment, 32 ALA. LAw 24 (1971).

111. See, e.g., Floyd v. Trice, 490 F.2d 1154 (81h Cir. 1974); Hawkins v. Coleman, 376 F. Supp. 1330 (N.D. Tex. 1974); Rhyne v. Childs, 359 F. Supp. 1085 (N.D. Fla. 1973), aff'd sub nom. Sweet v. Childs, 507 F.2d 675 (5th Cir. 1975). But see Boykins v. Fairfield Bd. of Educ.. 492 F.2d 697, 702 (5th Cir. 1974). See generally McClung, supra note 31, at 507-08.

II2. 327 F. Supp. 930 (S.D. Fla. 1971).

113. Id. at 932 
Tillman was followed by Rhyne v. Childs, ${ }^{114}$ which arose in Jackson County, Florida. The facts of that case were complex, and evidenced the deep social dislocations associated with school desegregation in an atmosphere of racial hostility. On January 3, 1972, black and white students at the Marianna High School engaged in a "general melee," and school officials were compelled to send the students home and cancel classes. School officials were threatened with bodily harm, and a number of students were armed with make-shift weapons. Three days later further disorders broke out, resulting in a temporary boycott by black students. While school authorities, and apparently the judge, did not attribute the disorders to any particular racial group, almost all of those disciplined were black. The plaintiffs, permanently excluded black students, introduced evidence of this disparity of treatment "in order to establish an overall scheme or pattern of racial discrimination." 115 The court held that the plaintiffs had not been denied their constitutional rights.

The court found that the plaintiffs threatened physical harm to school officials, and had shown disrespect toward them. Plaintiff Pittman, apparently among the many black students who had left the school campus on January 6, was temporarily suspended and then permanently expelled because "[h]is attitude at [a conference with school officials] was one of noncooperation and non-participation."116 Finding that there was evidence to support each of these disciplinary actions, the court then addressed itself to the allegation that there was a pattern of racial discrimination in these and other disciplinary actions: ${ }^{117}$

\begin{abstract}
The Court has considered the evidence, which standing alone, would constitute impressive. if not persuasive. statistics. But this allegation of discrimination must be viewed in light [sic] of all the testimony adduced. particularly that of five county school administrators whose testimony disclosed that this statistical disparity of suspensions of blacks vis-a-ris that of whites resulted in the main from the decision of black students to forego corporal punishment when a breach of discipline occurred and elect instead 10 be suspended from their classes. $B_{y}$ the same token the record is not devoid of instances where defendants have expelled or suspended white students for similar breaches of discipline.
\end{abstract}

The court then upheld the specific expulsion decisions challenged in the litigation, and by inference the overall disciplinary policies and procedures of the school district.

114. 359 F. Supp. 1085 (N.D. Fla. 1973).

115. Id. at 1090 .

116. Id. at 1089

117. Id. at 1090. The court of appeals, in affirming the lower court, dealt even more cryptically with the racial discrimination argument:

On appeal, appellants again comlend that the disciplinary actions which befell them. . were parts of a larger pattern of racial discrimination that pervaded the Jackson County School system. The gist of the argument is to make out a mathematical 
The Rhyne decision is unsatisfying on a number of grounds as the court attempts to grapple with legal and factual issues that appear beyond its grasp. The court never specifies the number of white students who were suspended as a result of the outbursts, and only in the most sketchy terms refers to the fact that overall, black students are suspended or expelled more often than white students. When pushed for an explanation, the court carefully points out that black students, when given the choice of corporal punishment or exclusion, usually pick the latter. But why should this explanation suffice? How many black students, as compared with white students, allegedly commit infractions which lead to this choice of punishments? Do the data on white students show that the number receiving corporal punishment is roughly in proportion to the white percentage of the school population? Why do blacks choose exclusion more often than whites? Might it be because school officials urge them to make this choice? Because school officials beat black children more vigorously than white children? Because black children are so alienated by the school environment that they seize any opportunity to escape? Because black parents are able to put less pressure than white parents on school officials to avoid the imposition of more severe penalties? Furthermore, one must assume that corporal punishment is an alternative only to short-term suspensions, yet all of the named plaintiffs in the suit had been permanently expelled. If there is a disparity in expulsions and long-term suspensions as well as in short-term suspensions (the court never informs us), the corporal punishment/exclusion choice argument would not suffice as an explanation.

The Rhyne court, understandably, confuses the individual claims of the named plaintiffs with the allegation that there is an overall pattern of racial discrimination in the county's disciplinary policies. The court first concludes that there is substantial evidence in the record to justify each of the expulsions under attack. There is no evidence of racist behavior on the part of individual teachers and administrators. It then turns to the allegation of a pattern of discrimination as if it were a completely separate claim. Yet, obviously the plaintiffs, at a minimum, are asserting that there were white students who had engaged in similar behavior who were not punished, or at least not as severely, and that regardless of their individual culpability, their expulsions should be set aside. The court does not perceive the relationship between these claims. The reason for this may be that it is difficult for the court to accept the proposition that the infractions of the plaintiffs should

equal protection argument: more black students had been disciplined than whites, hence, a violation of the equal protection clause. The answer to the argument is that it lacks a factual foundation. There was no showing of arbitrary suspensions or expulsions of black students nor of a failure to suspend or expel white students for sinilar conduct.

Sweet $x$ Childs, 507 F.2d 675, 680-81 (51h Cir. 1975). 
be forgiven, simply because there are others who have committed wrongs who have not been punished, or because blacks on other occasions may have been punished unfairly. The problem smacks of the issues associated with prosecutorial discretion in criminal law, and the unwillingness of courts to overturn convictions where all those allegedly guilty have not been charged and convicted.

A second reason for the court's hesitancy is that a ruling favorable to plaintiffs might require it to review each disciplinary action of school authorities in the future to make sure that black students were not treated in a discriminatory fashion. Given the factual complexities of school discipline and the degree of judicial intrusion that would be required, the court was less than enthusiastic. Finally, the adoption of the plaintiffs' argument would label the school system of Jackson County as racist, and whatever the truth of the matter, the court may have been reluctant to attach such a stigmatizing and all-encompassing label to the administrators and teachers in that system. Thus, irrespective of the statistical showing of disproportionality, the court was perfectly willing to adopt the spurious corporal punishment argument to avoid this result. Simultaneously, it refused to place the blame for the outbursts on the black students, retreating to an examination of the conduct of each of the named plaintiffs in the litigation.

Despite its hostility to the plaintiffs' racial discrimination arguments, the court's opinion reveals a number of the dilemmas underlying black exclusion. The case arises in the context of violent confrontations between black and white students and school officials, and yet not a single plaintiff was expressly expelled for his part in those disorders. Instead, the plaintiff students were accused of refusing to yield to authority, of disrespect for school officials, of unauthorized absence from the campus, and of holding attitudes of non-cooperation and non-participation. In a number of instances, expulsion was grounded not only on these specific acts, but also on past acts of disobedience. To be sure, a number of the plaintiffs had engaged in physically threatening behavior, but the gist of the cases against them was their failure to abide by the institutional rules relating to scheduling, decorum, and respect for authority. ${ }^{118}$ This reinforces the theory that an effective attack on black exclusion from the perspective of "institutional racism" would require an assault on the "hidden curriculum" of public schools.

While the court was unwilling to undertake such a task, it was willing to weigh the gravity of the plaintiffs' infractions against the magnitude of

118. Indeed, the court dismissed the claims of four of the plaintiffs for failure to answer interrogatories propounded by the school district pursuant is Rule $37(\mathrm{~d})$ of the Federal Rules of Civil Procedure. 359 F. Supp. at $1088 \mathrm{n}$. . These plaintiffs also were not available at the hearing in the case to answer defendants questions, as counsel admitted "that he has been unable to communicate with [theml." Id. Thus their claims were dismissed largely because they failed to respect the court's authority, rules. and time schedules. 
their punishment. Inexplicably, and without extended discussion or citation to authority, the court took it upon itself to reduce the penalties imposed on the plaintiffs from permanent expulsion to exclusion until the end of the school year, arguing that the former is too harsh under the circumstances: ${ }^{119}$

It is this Court's view that expulsion was warranted; however, the severity of the punishment meted out by the defendant school board does not appear commensurate with the severity of the acts committed and this Court is of the view that the expulsions should not be made permanent but that they be lifted after the present school year terminates.

Thus for the court, the issue is one of making the punishment fit the crime, rather than one of scrutinizing the substantive rules which lead to disciplinary actions. In my view this is appropriate. What is lacking is a satisfactory legal theory to allow the court to reach this result, and a greater sensitivity to the injury done by exclusion. Permanent exclusion is too harsh, but what of temporary exclusion? The court never considers requiring school authorities to explore alternative placements for the expelled students or to provide make-up educational services to them while they are officially banished from the high school building. Despite the fact that a number of the plaintiffs could not be found by their own counsel, ${ }^{120}$ the court does not comprehend the fact that even expulsion for the remainder of the semester may lead to a permanent severing of ties with the institution. Moreover, the court makes no effort to communicate to school authorities the necessity of limiting long-term suspension and expulsion to only the most serious violations of school rules, implicitly leaving them free to apply any exclusion sanction short of permanent expulsion.

The only successful constitutional assault on black exclusion, viewed as an instance of racial discrimination, occurred in Hawkins $v$. Coleman, ${ }^{121}$ decided by Judge Sarah Hughes in June of 1974. Until the summer of 1971 , the Dallas Independent School District continued to operate a dual school system, and after that date, pursuant to court order, students were reassigned in order to achieve a unitary school system. ${ }^{122}$ Black students were transferred from schools in which they were in the majority to those in which they were in the minority. In the wake of this desegregation program, massive numbers of black students were suspended, ${ }^{123}$ and plaintiffs, representing the class of black students attending majority white schools, contended that disciplinary rules were applied in a racially discriminatory manner. In order

119. 359 F. Supp. at 1095. The court of appeals did not disturb this aspect of the lower court's order, but simply described it in a footnote, failing to offer any legal reasoning to support the reduction in punishment. Sweet v. Childs, 507 F.2d 675, 678 n. 5 (5th Cir. 1975).

120. See note 118 supra.

121. 376 F. Supp. 1330 (N.D. Tex. 1974).

122. See Tasby v. Estes, 342 F. Supp. 945 (N.D. Tex. 1971)

123. See note 50 supra. 
to demonstrate such discrimination, plaintiffs introduced statistical evidence showing that 60.5 per cent of all students suspended in 1972-73 were black, whereas blacks constituted only 38.7 per cent of the total enrollment. For the fall semester of 1973, the figures on suspension were virtually identical. In addition, as if to meet the argument made by the court in the Rhyne case, plaintiffs proved that over the same period of time, more blacks than whites were corporally punished. ${ }^{124}$ For both corporal punishment and suspension, disparities between the races were greater within majority white schools than in the system as a whole-although there were significant differences between majority white schools in this respect. For example, in the Woodrow Wilson High School blacks constituted less than 14 per cent of the enrollment and yet accounted for more than 83 per cent of the three to ten day suspensions. In contrast, there were six junior and senior high schools, with black populations of from 1 per cent to 39.2 per cent, that did not impose a single three to ten day suspension during the fall of $1973 .{ }^{125}$

The court then proceeded to examine the reasons for the overrepresentation of blacks among suspended students. The court found that fully 60 per cent of all suspensions were for non-violent infractions such as truancy, class cutting, and disrespect for teachers. ${ }^{126}$ From this data and the raw statistics on the incidence of suspension between whites and blacks, experts drew the conclusion that the disciplinary policies of the Dallas Independent School District (DISD) were infected with "institutional racism": ${ }^{127}$

[T] $T$ he DISD fit [sic] into an existing national pattern of race discrimination in that the DISD is a "white controlled institution" with "institutional racism" existing in the operation of its discipline procedures. . . "Institutional racism" exists .. When the standard operating procedures of an institution are prejudiced against, derogatory to, or unresponsive to the needs of a particular racial group. . .

Because of the existence of racism . . black students will become more frustrated as the institution continues to refuse to respond to their needs and ambitions. This frustration will be reflected either in increased passivity or increased hostility. Such hostilities will result in increased "suspendable behavior" . . . Moreorer . . . in a school district in which there is institutional racism toward the Blacks conduct by black students that would not be "unusual" or "offensive" in a black environment becomes to many teachers "disruptive" or "suspendable conduct." To teachers unfamiliai with Blacks, this conduct. that is non-riolent and characteristic of the black race, stands out and becomes thereby subject to selective persecution.

The piece de resistance of the testimony, however, was given by Dr. Nolan Estes, Superintendent of the Dallas school system. When asked to explain

124. Hawkins v. Coleman, 376 F. Supp. 1330, 1333 (N.D. Tex. 1974). For a general discussion of recent corporal punishment cases, see Note, Corporal Punishment. 53 Tex. L. Rev. 355 (1975).

125. 376 F. Supp. at 1334 .

126. 376 F. Supp. at 1335

127. 376 F. Supp. at 1336. 
the high rate of suspension, Dr. Estes, apparently to the amazement of all concerned, replied, "'Well, we are a White controlled institution, institutional racism, racism among individuals." "128 In the absence of testimony rebutting Dr. Estes' statement and the statements of the two other experts called in the case, the court concluded that "institutional racism" was indeed responsible for the disproportionality between the races in rates of suspension and that the school district was constitutionally required to take steps to overcome it. To this end, Judge Hughes issued the following order: ${ }^{129}$

While not attempting to dictate the details of an affirmative program this Court does direct the DISD to review its present program and to put into effect an affirmative program aimed at materially lessening "white institutional racism" in the DISD.

Hawkins, like Rhyne, is consistent with the theory that black exclusion is largely a product of the institutional rules, relating to decorum, respect for authority, and timeliness. In addition, the disparities in suspension rates between majority white schools may indicate some measure of personal racism on the part of teachers and principals, in some schools, variations in the socioeconomic composition of the student bodies between schools, or a diversity of attitudes with respect to the wisdom of employing exclusion sanctions. However, the court's simplistic conclusion, based upon the testimony of expert witnesses, that institutional racism permeates the Dallas school system must be taken with a grain of salt. The experts, adopting an attitude of cultural fatalism and superiority, seem to assume that black students are incapable of complying with the "hidden curriculum" and that it necessarily follows that the cultural characteristics of blacks are to be preferred to the cultural characteristics demanded by the Dallas public schools. Neither of these positions is necessarily correct. Indeed, while there may well be experts on the characteristics of black people-although I observe no unanimity among those experts - I am dubious that there are experts who can inform the courts as to whether one set of cultural values is superior to another set. Furthermore, this approach ignores the possibility of value accomodation in the public schools, preferring instead the all or nothing cultural choice. Were it not for the admission of racism by the chief administrative official of the school system, one wonders whether the court would have been so willing to find a pattern of institutional racism. This admission largely obviated the need to examine racially neutral pedagogical and institutional reasons which would explain the statistics on black exclusion.

But the most intriguing aspect of Hawkins is the remedy ordered by the court. Once it is determined that institutional as opposed to personal racism is the culprit, where does this leave the court and the parties in terms of a

128. Id.

129. 376 F. Supp. at 1338 
remedy? Does it mean that blacks may no longer be suspended, while whites may be suspended? Should quotas be set, with black suspensions not to exceed a predetermined number? Are these remedies appropriate even where the evidence clearly demonstrates that individual black youngsters have engaged in "suspendable" behavior? The court opted, in the most hortatory tone, to order the school district to do and think "right." And yet, as the court readily admitted: ${ }^{130}$

No court can decree a change in attitude. That is something within the individual. Put briefly, there must be a real effort on the part of everyone involved to accentuate the positive while at the same time climinating the negative effects of "white institutional racism."

If the court had more carefully analyzed the problem, it might just as well have admitted the necessity to completely restructure the schooling environment to eliminate the institutional rules which blacks most often violate. While I would be the last to take the position that there is no value in symbolic decrees which cannot be easily translated into specific actions by public officials, ${ }^{131}$ the court, in effect, admitted its powerlessness to address the black exclusion problem when the legal arguments are cast in terms of institutional racism. Whatever the merits of that argument, and $1 \mathrm{am}$ dubious, it does not lend itself to a meaningful remediation of the asserted injury.

In the absence of proof of individual racial bias, a more meaningful approach would have been to compel the school district to limit the number and types of infractions for which suspension would lie and to institute a program of alternative placement or out-of-school services to those suspended. Many schools in the Dallas system have demonstrated their ability to maintain order, and presumably educate, without relying substantially upon an exclusion sanction. This would have had the effect of ameliorating a great portion of the injury suffered by plaintiffs and their class, and simultaneously, of extending that remedy to many white children who also suffer from exclusion.

\section{Nonracial Approaches to Exclusion: Rodriguez and Beyond}

The translation of the proposition that exclusion of public school students is an inappropriate sanction for violations of school rules into constitutional law is not without its difficulties. Lower court judges have occasionally made this point, ${ }^{132}$ but the general attitude has been that the severity of the

130. $I d$.

131. See Yudof. supra note 24, at 414-16. But see Kurland, Equal Educational Opportunity: The Limits of Constitutional Jurippudene Undefimed, 35 L. C.HI. L. REV. 583, 598-600 (1968).

132. See, e.g., Boykins v. Fairfield Bd. of Educ, 492 F.2d 697, 702 (5th Cir. 1974) (Godbold, J.. dissenting); Lee v. Macon County Bd. of Educ. 490 F.2d 458. 460 n. 3 (5th Cir. 1974) (dicta); Cook v. Edwards, 341 F. Supp. 307. 311 (D.N.H. 1972); $f$. Strickland v. Inlow, 485 F.2d 186 (8th Cir. 1973), vacated and remanded sub mom. Wood v. Strickland, 95 S. Ct. 992 (1975). 
punishment, except as it relates to the necessity for and nature of a due process hearing, ${ }^{133}$ is a legislative and administrative matter. ${ }^{134}$ This is consistent with traditional judicial attitudes toward the imposition of punishment in the criminal law context. ${ }^{135}$

The judicial attitude toward review of punishments appears to emanate from concepts of the appropriate role of the judiciary in such matters. What is excessive either absolutely, or under the circumstances, is by its very nature a subjective determination, wholly lacking in precision. Where lines must be drawn by someone, and where it is difficult to articulate standards under which to test that line drawing, the tendency is to affirm the determinations of legislative and administrative authorities. Judicial review of the infraction-punishment nexus smacks of substantive due process since it contemplates substitution of the court's judgment for that of more representative branches of government. This is particularly true where the applicable test is likely to be of the "shocks the conscience" variety. ${ }^{136}$ This is all the more the case in a civil rather than criminal context, where the textual constitutional arguments are weaker (the eighth amendment does not apply) and the disability is often less serious.

Of course, all of us can find school exclusion cases where the courts have demonstrated a picayune concern for procedure and technicality where, at bottom, they were appalled by the severity of the punishment. While substantive due process attacks on exclusion are rare, ${ }^{137}$ given the Court's hostility

133. See, e.g., Goss v. Lopez, 419 U.S. 565 (1975): Hagopian v. Knowlton. 470 F.2d 201 (2d Cir. 1972); Banks v. Board of Pub. Instruction, 450 F.2d 1103 (5th C.ir. 197l); Madera v. Board of Educ., 386 F.2d 778 (2d Cir. 1967). See generally Buss, Procedural Due Process for School Discipline: Probing the Constitutional Outline, 119 U. PA. L. Rev. 545 (1971).

134. See, e.g. Boykins v. Fairfield Bd. of Educ, 492 F.2d 697 (5th Cir. 1974); Ferguson v. Thomas, 430 F.2d 852 (5th Cir. 1970); cf. Wood v. Strickland, 420 U.S. 308 (1975).

135. See United States v. Cleveland, 503 F.2d 1067, 1071 (91h Cir. 1974); Packer, Making the Punishment Fit the Crime, 77 HaRv. L. REv. 1071 (1964). To take an extreme example from criminal law, witness the inability of the justices of the Supreme Court to agree on a common approach toward the constitutionality of the death penalty under the eighth amendment. Furman v. Georgia, 408 U.S. 238 (1972). If four of the justices cannot be persuaded to overturn dearh sentences, the case for overturning school exclusions, a non-criminal penalty to which the eighth amendment does not apply, would appear hopeless. But note that the severe penaly imposed by the state in that case was occasioned by the commission of the most heinous crimes. rape and murder. If "Shuffling Sam," found guilty of loitering and disorderly conduct, Thompson v. Louisville, 362 L.S. 199 (1960), had been sentenced to death, the justices would have had litule difficulty with the constitutionality of the punishment. Cf. Ralph v. Warden Maryland Penitentiary, 438 F.2d 786 (4th Cir. 1970). Indeed, there are a handful of cases which appear to be pushing the criminal law in this direction. See, e.g., Trop v. Dulles, 356 U.S. 86 (1958); In re Lynch, 8 Cal. 3d 410, 503 P.2d 921, 105 Cal. Rptr. 217 (1972); Ralph v. Warden Maryland Penitentiary, 438 F.2d 786 (4th Cir. 1970); Robinson v. California, 370 U.S. 660 (1962) (dicta); Weems v. United States, 217 U.S. 349 (1910) (plurality opinion). See generally Packer supra. But this is hardly dispositive of school exclusions.

136. See note 137 infra.

137. See. e.g.. Jenkins v. Louisiana State Bd. of Educ, 506 F.2d 992, 1001-02 (5th Cir. 1975) ("no evidence" to justify suspension); Boykins v. Fairfield Bd. of Educ., 492 F.2d 697 (5th Cir. 1974); Strickland v. Inlow, 485 F.2d 186 (8th Cir. 1973), vacated and remanded sub nom. 
to that mode of judicial analysis, judicial intervention generally occurs in first amendment school cases only where the sanction of suspension or expulsion is employed. ${ }^{138}$ But it should be noted that the equal protection clause may also serve this function. If a punishment is unduly harsh, authorities may hesitate to make it generally applicable, straining to limit it to a particular class which they view as deserving of opprobrium. This in turn invites an equal protection challenge which may leave authorities with the Hobson's choice of abolishing the punishment or limiting its application in a more defensible, narrower fashion. While it is the classification which demands judicial scrutiny, the invalidation of the classification influences the choice and use of sanctions. In addition, the nature of the punishment itself may be decisive. If the punishment deprives the plaintiff of the enjoyment of highly significart privileges-what has been called a "fundamental interest"-the courts may impose a burden of justification on the state which invariably it cannot carry. ${ }^{139}$ In such cases, the judicial message is clear: punishments of this sort are disfavored.

With respect to exclusion, the relevant classification is between those permitted to continue attending public schools or otherwise receive an education at public expense, and those who are not. The courts must be persuaded that the designation of these students for exclusion, who have committed relatively minor violations of the hidden cirriculum or who, having committed more serious offenses, have been denied out-of-school public educational services, is not a reasonable classification. Under the traditional

Wood v. Strickland, 95 S. Ct. 992 (1975); Cook v. Edwards, 341 F. Supp. 307, 311 (D.N.H. 1972). See generally McClung, supra note 31. Judge Godbold of the Fifth Circuit has argued forcefully for a due process limitation on the power of boards of education to exclude students for minor infractions of school rules:

[The court hopes that the parties will settle their dispute] without the necessity of . . repairing again to the federal courthouse for a judicial decision of whether there is such disparity between the offenses and the penalty that the commands of the fourteenth amendment have not been met.

Lee v. Macon County Bd. of Educ., 490 F.2d 458, 460 (5th Cir. 1974) (dicta).

Such a case can, of course, arise. Clearly, for example, a school board could not constitutionally expel forever a pupil who had committed no offense other than being five minutes tardy one time. . . .

... [This does] not license federal judges to review and revise school board disciplinary actions at will. Application is limited to the rare cases where there is shocking disparity between offense and penalty.

Id. at 460 n. 3. See also Boykins v. Fairfield Bd. of Educ., 492 F.2d 697, 702 (5th Cir. 1974) (Godbold, J., dissenting); Paine v. Board of Regents of University of Texas Sys., 355 F. Supp. 199 (W.D. Tex. 1972). Anderson v. Independent School Dist. No. 281, Civil No. 42043 (Dist. Ct. Minn., Feb. 18, 1969), appeal dismissed as moot, 289 Minn. 515, 176 N.W.2d 640 (1970); unreported injunctive order cited in S. Goldstein, supra note 63, at 439.

138. See Eisner v. Stamford Bd. of Educ., 440 F.2d 803 (2d Cir. 1971). See generally Educational Policy and the Law 139-74, 190-97.

139. See generally Goodpaster, The Constitution and Fundamental Rights, 15 Ariz. L. REv. 479 (1973); Gunther, The Supreme Court, 1971 Term-Foreword: In Search of Evolving Doctrine on a Changing Court: A Model for a Newer Equal Protection, 86 HARv. L. REv. 1 (1972). 
rational basis test, this result is unlikely. To the extent that a relatively loose tie between the state's interest in maintaining order in the public schools and the exclusion device will suffice, and this is the conclusion that the attachment of the rational basis test label would portend, the courts cannot be expected to overturn exclusion practices. Even out-of-school services may not be ordered on the ground that preservation of the public fisc is a sufficient state interest. To the extent that the courts recognize the importance of the continuation of the public educational experience to the student, the courts, whatever their conclusionary labels, will require a closer nexus between this extraordinary action and the state's educational objectives. If, as is clearly the case, most infractions can be punished and deterred by lesser sanctions, the courts may require education authorities to resort to these alternatives. Even where exclusion from regular schools or classes is justified, the courts may affirm the right of students to some nontraditional, publicly funded, form of education.

Without belaboring the well discussed variations in equal protection standards, ${ }^{140}$ the success of exclusion litigation will depend on the willingness of courts to treat education, at least in this context, as a substantial personal interest which, in the ad hoc process of weighing competing interests, requires the state to stop short of termination for violation of school rules. For nearly twenty years after Brown v. Board of Education, ${ }^{141}$ there was a widespread belief among commentators that education was such an interest. Almost invariably, scholarship in the law and education field began with the famous litany from Brown: "Education is perhaps the most important function of state and local governments . . . "142 This became less an assertion of fact, for surely at that level there could be no dispute, than an invocation of the constitutional deity of a "fundamental interest." In 1973, however, the Supreme Court rejected the wisdom of the earlier prophets. Fearing an avalanche of litigation relating to non-education public services, the Court held that education was not a fundamental interest triggering a higher degree of judicial scrutiny. ${ }^{143}$ While admitting its relationship to voting and the exercise of first amendment rights, the Court barely left the door ajar: ${ }^{144}$

Even if it were conceded that some identifiable quantum of education is a constitutionally protected prercquisite to the meaningful exercise of either right, we have no indication that the present levels of educational expenditures in Texas provide an education that falls short... [N] tharge

140. Ser note 139 supra.

141. 347 U.S. 483 (1954).

142. Id. at 493. Se' gemerally J. CoOns, W. Cinne, \&. Sugarman, supra note 89.

143. San Antonio Independent School Dist. v. Rodriguez, 411 U.S. 1 (1973). See generally Yudof, supra note 24, at 500; Comment. San Antonio Independent School Dist. $\checkmark$ Rodriguez: A Retreat From Equal Protection, 22 Ciev. ST. L. Rev. 585 (1973).

144. Id. al 36-37. 
fairly could be made that the system fails to provide each child with an opportunity to acquire the basic minimal skills necessary for the enjoyment of the rights of speech and of full participation in the political process.

In the absence of a racial classification and given the Court's extraordinary requirements for the establishment of a wealth classification, analysis of the school exclusion problem from an equal protection perspective must begin with a charitable reading of this dictum.

In Rodriguez, the plaintiffs asserted that Texas school financing laws created an unconstitutional discrimination between children living in property-poor districts and those living in more affluent districts. By relying on the local ad valorem property tax, and in the absence of state equalization, rich districts were able to offer a high cost education at low tax rates. Conversely, in poor districts, exorbitant tax rates yielded a second class public education. Both with respect to the class of plaintiffs, alleged to be personally poor, and the nature of the deprivation, the Court held that a relative denial of educational opportunities did not constitute a violation of the equal protection clause. ${ }^{145}$ The clear inference, supported by few explicit statements, was that a complete denial of all educational opportunities might well constitute a denial of constitutional rights. If this is the case, then the argument in the present context must be that suspension and expulsion constitute such a denial, and thus are constitutionally impermissible. ${ }^{146}$

With respect to permanent exclusion, the applicability of the Rodriguez caveat is clear; a student permanently banished from the public schools, and not offered a public education outside of the school building, has been denied all opportunity to obtain an education. For those unable to afford a private education, this is unavoidable. For those expelled for a full semester or remainder of a semester, or suspended for days or weeks, the applicability of the Rodriguez caveat is less clear. The problem is both semantic and practical. The denial of an education is absolute for the period of time that the sanction remains in effect, but it is only partial or relative in comparison to the eight to twelve years that most students attend public elementary and secondary schools. There is a practical problem in that it is unrealistic to treat a one-day suspension as the equivalent of a full semester's expulsion. In terms of the injury done to the student, which is likely to be relatively trivial in a short-term suspension, and the weight of the state's interest, which may

145. Id. at $\mathbf{5 5}$.

146. Private citizens, law making bodies, and the media all bend their efforts toward encouraging children to complete their high school educations and to avoid becoming dropouts and burdens to society. In the twenty years since Brown v. Board of Education this country has committed itself to a policy against state-imposed public school segregation. It is not lesser but more stringent state action to bar a child forever from public school, with the result that he secures no education at all.

Lee v. Macon County Bd. of Educ., 490 F.2d 458, 461 (5th Cir. 1974). See generally McClung, supra note 31 . 
be great where a short cooling off period may avoid future turmoil, a distinction is justified. ${ }^{147}$ While there can be no precise line between a relative and absolute denial, and between an exclusion with significantly injurious consequences and one without, I would suggest a functional approach. Where the exclusion is of such a duration as to make the child fall significantly behind in his work or so as to otherwise jeopardize his continued attendance at public school, he has been denied equal protection of the laws unless there is no feasible alternative to removal from the school and other placements have been explored. My own sense is that generally this threshold point is reached when a student is suspended for two or more weeks, although on occasion, a shorter exclusion may have dire consequences. ${ }^{148}$ Such an equal protection approach has been successfully employed by retarded, ${ }^{149}$ truant, ${ }^{150}$ pregnant, ${ }^{151}$ emotionally disturbed, ${ }^{152}$ and alien children ${ }^{153}$ to attack exclusion decisions. ${ }^{154}$ Most of these cases were decided before Rodriguez, but there does not appear to be a great ground swell to reverse them. ${ }^{155}$ The case most directly on point is Mills $v$. Board of Education, ${ }^{156}$ brought on behalf of an estimated 22,000 "exceptional" school children who were excluded from the public schools of the District of Columbia. The category of "exceptional" children included not only the mentally retarded, the physically handicapped, and the hyperkinetic, but, more generally, all of those children with "behavioral problems," regardless of the causes. The court, operating in the golden days before Rodriguez, reasoned that if a denial of an equal educational opportunity were constitutionally infirm, there could be no doubt about complete exclusion: ${ }^{157}$

In Hobson v. Hansen, [269 F. Supp. 401 (D.D.C. 1967)], Judge Wright found that denying poor public school children educational opportunities equal to that available to more affluent public school children was violative of the [Constitution] . . . A fortiori, the defendants conduct here, denying plaintiffs and their class not just an equal publicly supported education but all publicly supported education while providing such education to other children, is violative of the [Constitution].

147. See Goss v. Lopez, 419 U.S. 565, 584 (1975) (Powell, J., dissenting).

148. Shanley v. Northeast Independent School Dist., 462 F.2d 960, 967 n.4 (5th Cir. 1972).

149. Pennsylvania Assin for Retarded Children v. Commonwealth, 334 F. Supp. 1257, 343 F. Supp. 279 (E.D. Pa. 1971) (consent order). Sep Kirp, supra note 18, at 747-48; Herr, supra note 47 .

150. Knight v. Board of Educ., 48 F.R.D. 115 (E.D.N.Y. 1969).

151. See, r.g., Ordway v. Hargraves, 323 F. Supp. 1155 (D. Mass. 1971). See generally Comment, Marriage, Pregnancy, and the Right to Go to School, 50 Tex. L. Rev. 1196 (1972).

152. Mills v. Board of Educ., 348 F. Supp. 866 (D.D.C. 1972).

153. Hosier v. Evans, 314 F. Supp. 316 (D.V.I. 1970).

154. See generally Dimond, supra note 48; Kirp, supra note 18; McClung, supra note 31; Van Geel, supra note 48.

155. See McClung, supra note 31 ; Van Geel, supra note 48.

156. 348 F. Supp. 866 (D.D.C. 1972).

157. Id. at 875 . 
Despite its reliance on a poverty classification and on Hobson, the Mills decision is defensible today on the ground that a school system may not classify a group of youngsters for complete exclusion from the public educational system. The court recognized that not all children should be assigned to regular classes and that children with extraordinary needs and problems might require special attention. It ordered ${ }^{158}$

That no child eligible for a publicly supported education in the District of Columbia public schools shall be excluded from a regular public school assignment by a rule, policy, or practice of the board of education of the District of Columbia or its agents unless such child is provided (a) adequate alternative educational services suited to the child's needs, which may include special education or tuition grants, and (b) a constitutionally adequate prior hearing and periodic review of the child's status, progress, and the adequacy of any educational alternative.

The court further held that the asserted insufficiency of funds did not excuse exclusion, for the school district had a constitutional obligation to divide its funds equitably so as to assure that no child was completely denied all public educational opportunities. In other words, and this may give rise to litigation in the future, if the district did not have the financial wherewithal to meet the needs of all of its students, it must reduce its per pupil expenditures and could not refuse to educate particular classes of children. ${ }^{159}$

\section{Conclusion}

A legal approach premised on the unconstitutionality of a denial of all educational opportunity offers the greatest hope of undoing the injury occasioned by the disproportionate exclusion of black students from public elementary and secondary schools. While it is tempting to try to make the black exclusion problem fit the mold of racial discrimination, that approach misconceives the true nature of that problem, distorts reality, and, most important, does not yield a workable remedy.

Perhaps there are costs in failing to treat black exclusion as an aspect of racial discrimination. With Koestler's Rubashov, we may fear that revolutionaries and reformers who "think through other people's minds," who identify with others, and "who understand and forgive," cannot "find a motive to act."160 It is easier to arouse emotions and persuade to action, at least among the sympathetic, where there is racism, whether personal or institutional. But, in the long run, this approach will be counterproductive. Rather the responsibility for educating our young, both black and white, should be placed where it belongs, on the educational systems of the nation.

158. Id. at 878. See generally Kirp. Buss, \& Kuriloff, Legal Reform of Special Education: Empirical Studies and Procedural Proposals, 62 CaLIf. L. Rev. 40 (1974).

159. See Yudof, supra note 24, at 474-75; Kirp, supra note 18, at 782.

160. A. Koestler. Darkness at NoOn 23 (1955). 
When the right of every child to a public education is recognized, there will no longer be a black exclusion problem. But this is merely the beginning and not the end of the matter; for the ultimate goal must remain the successful implementation of educational programs for minority children. This, in turn, is dependent not only on their mere physical presence in public schools, but also on the development of new structures and pedagogical strategies adequate to the task. 